\title{
The Use of Natural Filter Media Added with Peat Soil for Household Greywater Treatment
}

\author{
Radin Maya Saphira Radin Mohamed (Author) \\ Department of Water and Environmental Engineering, \\ Faculty of Civil and Environmental Engineering, \\ Universiti Tun Hussein Onn Malaysia, \\ 86400 Parit Raja, Batu Pahat, Johor, Malaysia \\ maya@uthm.edu.my
}

\author{
Anwaruddin Ahmed Wurochekke (Co-Author) \\ Department of Water and Environmental Engineering, \\ Faculty of Civil and Environmental Engineering, \\ Universiti Tun Hussein Onn Malaysia, \\ 86400 Parit Raja, Batu Pahat, Johor, Malaysia \\ yadembo02@yahoo.com
}

\author{
Chee-Ming Chan (Co-Author) \\ Department of Water and Environmental Engineering, \\ Faculty of Engineering Technology, \\ Universiti Tun Hussein Onn Malaysia, \\ 86400 Parit Raja, Batu Pahat, Johor, Malaysia \\ chan@uthm.edu.my
}

\author{
Amir Hashim bin Mohd. Kassim (Co-Author) \\ Department of Water and Environmental Engineering, \\ Faculty of Civil and Environmental Engineering, \\ Universiti Tun Hussein Onn Malaysia, \\ 86400 Parit Raja, Batu Pahat, Johor, Malaysia \\ amir@uthm.edu.my
}

\begin{abstract}
Greywater is wastewater that produces $50-80 \%$ of overall water consumption in a house. In many village houses of Malaysia, the household greywater that comes from kitchen, laundry, bathroom and sinks is usually untreated and discharged directly into streams or rivers. This phenomenon escalates the pollution among Malaysian rivers. This study examines the effects of household greywater treated with locally available peat soil. This study was performed by using a two-stage filter media (i) pretreatment (gravel + sand) (ii) peat based (peat + charcoal + gravel). Effects of filtration on the peat soil were examined via the one-dimensional consolidation test and X-Ray Fluorescence Test (XRF). Removal efficiency of the greywater effluent was found to be TSS- $81 \%$, BOD- 54\%, COD - 52\% and AN - 87\%. pH of the greywater was improved from acidic (4.6) to neutral (6.9). Quality of the treated greywater complied with the limits of the Malaysian Standard (Standard B) for wastewater effluent discharge. The consolidation test was affected and became slower. XRF test indicates that peat soil has an increased amount of the inorganic content of Silicon Dioxide $\left(\mathrm{SiO}_{2}\right)$ and Aluminium Oxide $\left(\mathrm{Al}_{2} \mathrm{O}_{3}\right)$ associated with the absorption of certain elements in greywater. The peat based filter resulted in a substantial removal of pollutants. Further study is needed to look in depth the mechanism of adsorption and its applicability in a large scale processes.
\end{abstract}

Keywords- greywater, peat soil, filter media, sand, gravel, charcoal

\section{INTRODUCTION}

In many rural and sub-urban residential with decentralized system, a significant portion of greywater always ends up into stream without treatment. Problems of direct discharge of household greywater that comes from kitchen, laundry, baths and sinks have caused environmental concern in recent years. For many, especially in developing countries, the environmental outlook is gloomy. Furthermore, contamination the earth's surface, such as euthrophication of water bodies is more serious and more obvious and generates public environmental action. To solve these environmental problems, certain treatment procedures are necessary. Sustainable development has to be the main agenda regulated by federal, regional and municipal governments to limit environmental damage and to protect the environment for the benefit of future generations [1]. In this context, greywater should be well treated prior final discharge to the nearest river to protect public health and environmental pollution.

Greywater traditionally receives the least attention compared to other aspects of environmental sanitation, such as toilet wastewater or solid waste. Greywater contains suspended particles and some familiar organism such as pathogens, nutrients, and chemicals. For example, in studies on Swedish household wastewater, greywater is reported to contain $25 \%$ of the phosphorus and $10 \%$ of the nitrogen [2]. Previous data revealed that BOD levels indicate a high organic fraction was derived mostly from kitchen and bathing [2] [3]. High TSS which includes small amounts of oil, grease, soap residue, and organic materials may potentially clog the greywater treatment. The direct discharge of greywater to the drains and through the sewerage systems leads to oxygen depletion, increased turbidity, eutrophication as well as microbial and chemical contamination of the water resource system [3]. Tang et al., (2007) [4] stated that the unsustainable means of greywater discharge from residential affecting most of Malaysia's fresh water supply. Therefore, greywater treatment is necessary to ensure the greywater is released to comply with water quality standards.

Peat soil is classified as highly organic and representative material of soft soils [5]. According to Leong and Chin (1997) [6], peat soil is defined as a naturally occurring, highly organic substance derived primarily from plant materials (ASTM D4427-92, 1997). Peat is distinguished from other organic soil 
materials by its lower ash content (less than $25 \%$ ash by dry weight) and from other phytogenic material of higher rank (i.e., lignite coal) by its lower calorific value on a water-saturated basis [7]. The application of peat as a filter or natural sponge for cleaning up domestic wastewater and oily contaminated water has been studied for several years and the results suggest that peat is efficient in removing contaminants from water $(([3]$, [8], [9], [10], [11], [12], \& [13]). However, there is an absence data of the feasibility peat soil to enhance the removal of pollutants in household greywater.

This paper presents the capacity of the peat filled filter media in removing contaminants from household greywater in the village house case study. This includes an effectiveness of peat and other pre-treatment (sand and gravel) with the charcoal based filter that may be provide an extensive greywater treatment by filtering or absorbing impurities.

\section{MATERIALS AND METHOD}

\section{A. Greywater Sampling}

Greywater samples were collected at the effluent pipes of a single house in $\mathrm{Kg}$. Parit Haji Rasipan. This location was chosen because the greywater was directly discharge into drain by surface runoff. Sampling of greywater was done by composite method during during peak hours in the morning, lunch and night in 24 hours intervals. Sampling container preparation and preservation was done according to the Standard Method for Examination of Water and Wastewater [14].

Raw greywater was collected and analysed for the following parameters: total suspended solids (TSS) by the gravimetric method; biological oxygen demand $\left(\mathrm{BOD}_{5}\right)$ by five-day test; chemical oxygen demand (COD) by using COD reflux method, ammonium nitrogen (AN) by the Nesslerization method. All were measured by spectrometer using the $\mathrm{HACH} 2010$, an USEPA-approved method. In situ measurements of $\mathrm{pH}$ and Electroconductivity (EC) were obtained with an AQUA meter (TPS, Australia).

\section{B. Filter media Establishment}

Four model of filters were prepared to evaluate the replicacy settings. Control model was prepared to simulate the irrigation with tap water. The filter was using a container sized $410 \mathrm{~mm} \mathrm{x}$ $300 \mathrm{~mm} \times 255 \mathrm{~mm}$ and it can store about 20 liter of water. The filter was designed based on the gravity concept.

Filter consist two parts; (i) pre treatment process and (ii) peat + charcoal filter process. Pre treatment process contained gravel and sand layer. Pre treatment was a screening process where gravel was function to remove the particles and suspended solids from raw greywater. The second layer was filling up by sand. Sand was known as an effective filter media because of its ability to hold back coagulum or precipitates containing impurities. Sand filter are beds of granular material, drained from underneath so that greywater can be treated.
Peat filter consist three layer which are peat soil, charcoal and gravel. The peat soil filling up to 3 inch, charcoal 2 inch and gravel up to 2 inch. Charcoals were applied to remove the color and odor of greywater. According to Hernández-Leal et al, (2011) [15], charcoal filter can remove even micropollutants of greywater. Gravel was used as a base to support the overall filter system. The peat filter is filling in loose condition in order to allow greywater pass through the filter. Mosquito net and wire mesh were used to separate layer and to avoid the peat soil taken down during filtration process. Figure 1 shows the schematic diagram of filter media.

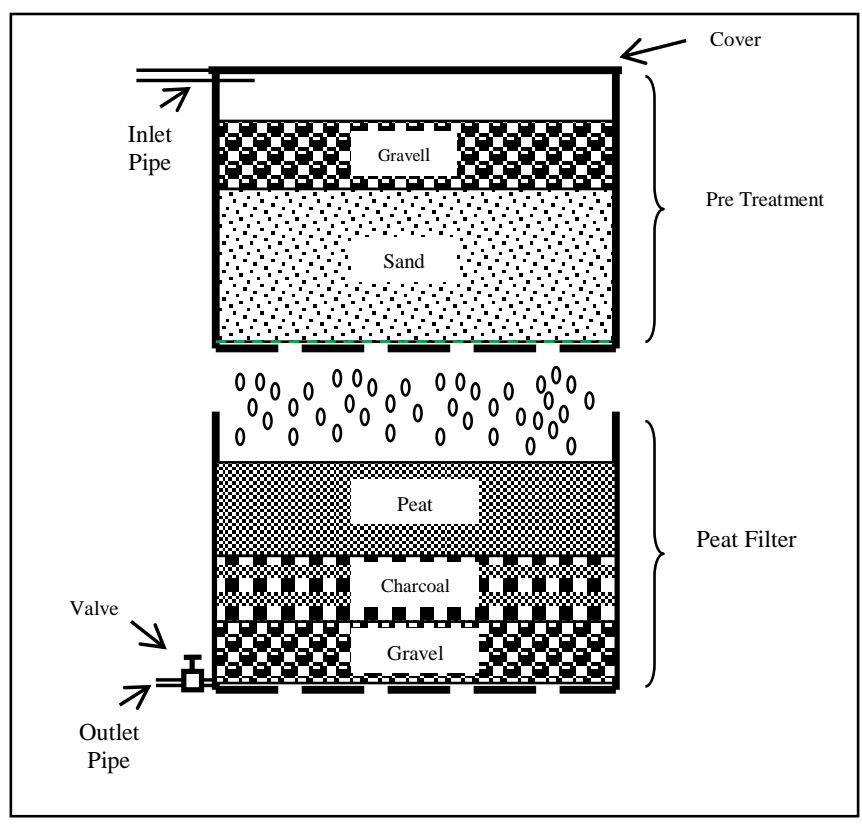

Figure 1. Schematic diagram of filter media

\section{Peat Soil Sampling}

Disturbed sampling was used for peat soils collected at the Kampung Parit Nipah, located about 10 kilometres from Universiti Tun Hussein Onn (UTHM). Samples were kept in plastic bag and tied up tightly in order to prevent any changing in the moisture content. Samples were then taken about 0.305 metre depth (1foot). All the samples were taken to geotechnical and RECESS (Research Centre for Soft Soils) laboratory and all soil tests were conducted in accordance with the British Standard BS1377: 1990.

\section{Peat Soil Analysis}

The physical and some selected mechanical properties of the peat soil sample from Kampung Parit Nipah, Batu Pahat Johor were determined. The tests were conducted by following the prescribed method in BS 1377 Method of test for Soil for civil engineering purposed:

i. Part 2: Classification test

ii. Part 3: Chemical and electro-chemical test 
iii. Part 5: Compressibility, Permeability and Durability tests

iv. Part 6: Consolidation and Permeability tests hydraulic cells and with pore pressure measurement

v. Part 7: Shear strength tests (total stress)

Peat soil analysis had been done to investigate the peat soil engineering properties of the post filtration. The tests onedimensional consolidation and X-ray fluorescence (XRF) test to determine any changes in their properties due to the reaction between peat soils with greywater. The properties of peat soil used in this study were shown in Table 1.

TABLE I. PROPERTIES OF PEAT SOIL IN KG. NIPAH, BATU PAHAT, JOHOR

\begin{tabular}{lc}
\hline \multicolumn{1}{c}{ Parameters } & Results \\
\hline Natural moisture content (\%) & 371 \\
Specific Gravity (Gs) & 1.25 \\
Acidity (pH) & 2.94 \\
Organic content (\%) & 49.72 \\
Sieve analysis & $60 \%$ Medium sand, 20 \\
& $\%$ Fine Sand \\
Ash content $(\%)$ & 50.3 \\
Liquid Limit $(\%)$ & 83 \\
\hline
\end{tabular}

\section{RESULTS AND DISCUSSION}

\section{A. Greywater Quality Before and After Treatment}

Summary data of the quality of greywater effluent after being treated with greywater were obtained and are shown in Table 2. It is observed that $\mathrm{pH}$ concentrations were acidic in raw greywater but were improved to neutral after being treated with peat soil. $\mathrm{pH}$ concentration in greywater is generally acidic (5.9-7.4) mostly contributed from organics compound in foods such as citrus fruits, pickles and sauces [16]. The $\mathrm{pH}$ of the treated greywater gradually increased from 4.6 to 6.9 with increasing duration of time possibly due to decomposition of organic materials into peat soil. Furthermore, peat is mainly a positively charged. Negatively charged particles in the greywater effluent are highly attracted to peat and will adhere to the peat. As the greywater flows through the peat, particles are absorbed by the peat and removed from the flow. Treated greywater also have shown better quality during the period of treatment by the reduction of BOD, COD, AN, TSS and turbidity concentrations.

TABLE II. SUMMARY OF GREYWATER QUALITY BEFORE AND AFTER TREATED WITH NATURAL FILTER MEDIA WITH PEAT SOIL (NO. OF SAMPLES, $\mathrm{N}=3$; MEAN \pm STANDARD DEVIATION)

\begin{tabular}{|c|c|c|c|c|c|c|c|c|}
\hline \multirow[t]{3}{*}{ Parameter } & \multicolumn{8}{|c|}{ Greywater concentration $(\mathrm{mg} / \mathrm{L})$} \\
\hline & \multicolumn{2}{|r|}{ Day 1} & \multicolumn{2}{|r|}{ Day 7} & \multicolumn{2}{|c|}{ Day 14} & \multicolumn{2}{|c|}{ Day 28} \\
\hline & $I$ & $E$ & $I$ & $E$ & $I$ & $E$ & $I$ & $E$ \\
\hline $\mathrm{pH}$ & 4.6 & $\begin{array}{ll}6.9 & \pm \\
0.2 & \end{array}$ & 4.2 & $6.6 \pm 0.1$ & 4.71 & $\begin{array}{ll}6.8 & \pm \\
0.2 & \end{array}$ & 4.4 & $\begin{array}{ll}6.9 & \pm \\
0.2 & \end{array}$ \\
\hline BOD & 75 & $61 \pm 4$ & 72 & $48 \pm 5$ & 67 & $37 \pm 2$ & 69 & $32 \pm 2$ \\
\hline
\end{tabular}

\begin{tabular}{|c|c|c|c|c|c|c|c|c|}
\hline$(\mathrm{mg} / \mathrm{L})$ & & & & & & & & \\
\hline $\begin{array}{l}\mathrm{COD} \\
(\mathrm{mg} / \mathrm{L})\end{array}$ & 149 & $\begin{array}{l}122 \pm \\
7.55\end{array}$ & 143 & $\begin{array}{ll}98 & \pm \\
15.63 & \end{array}$ & 128 & $\begin{array}{l}73 \pm \\
5.03\end{array}$ & 135 & $\begin{array}{ll}66 & \pm \\
4.04\end{array}$ \\
\hline $\mathrm{AN}(\mathrm{mg} / \mathrm{L})$ & $\begin{array}{l}12.8 \\
3\end{array}$ & $\begin{array}{l}8.28 \pm \\
0.27\end{array}$ & $\begin{array}{l}15.3 \\
0\end{array}$ & $\begin{array}{ll}4.32 & \pm \\
0.21 & \end{array}$ & 12.74 & $\begin{array}{l}1.54 \pm \\
0.17\end{array}$ & 13.30 & $\begin{array}{l}1.73 \pm \\
0.07\end{array}$ \\
\hline $\begin{array}{l}\text { TSS } \\
(\mathrm{mg} / \mathrm{L})\end{array}$ & 12 & $\begin{array}{ll}205 & \pm \\
16 & \end{array}$ & 296 & $176 \pm 8$ & 234 & $53 \pm 6$ & 212 & $40 \pm 3$ \\
\hline $\begin{array}{l}\text { Turbidity } \\
\text { (NTU) }\end{array}$ & 298 & $\begin{array}{l}193.3 \pm \\
16.26\end{array}$ & 267 & $\begin{array}{ll}164.3 & \pm \\
7.37\end{array}$ & 210.0 & $\begin{array}{l}43.7 \pm \\
5.03\end{array}$ & 198 & $\begin{array}{l}31.7 \pm \\
3.50\end{array}$ \\
\hline
\end{tabular}

\section{Note: $I=$ Influent, $E=$ Effluent}

The removal percentage of TSS on $14^{\text {th }}$ day and $28^{\text {th }}$ day was increased up to $77 \%$ and $81 \%$ (Figure 2). Research conducted by [17] had shown peat acts as a very effective filter for removing TSS from wastewater. However, the sorptive mechanism of the TSS with peat soil has not been detailed. The other reason may cause by the pre-treatment using a sand filter which is designed to trap suspended solids for raw greywater during the filtration process.

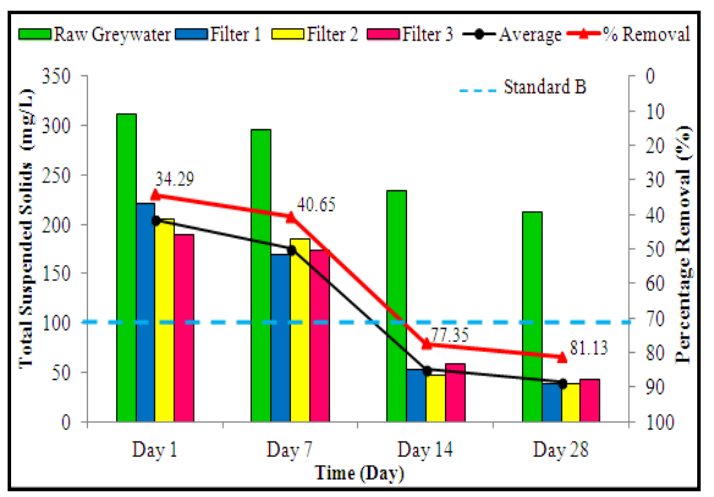

Figure 2. C

oncentration of TSS and its percentage removal during the treatment period

Figure 3 shows regression plot was used in order to determine if there was a correlation between TSS and BOD in the treatment of raw greywater using peat soil filter. The regression line $\left(\mathrm{R}^{2}=0.92\right)$ in the plot showed that there was a positive correlation between the TSS and the BOD. This finding suggests that a significant fraction of the TSS was organic and degradable. Figure 4 shows the graph of the BOD concentration. BOD for treated greywater indicates downward trend from the $1^{\text {st }}$ day until $28^{\text {th }}$ day with the higher percent BOD concentration up to $54 \%$. The high $\mathrm{BOD}_{5}$ is attributed to the kitchen and bath effluents that had high activities occurred in the house.

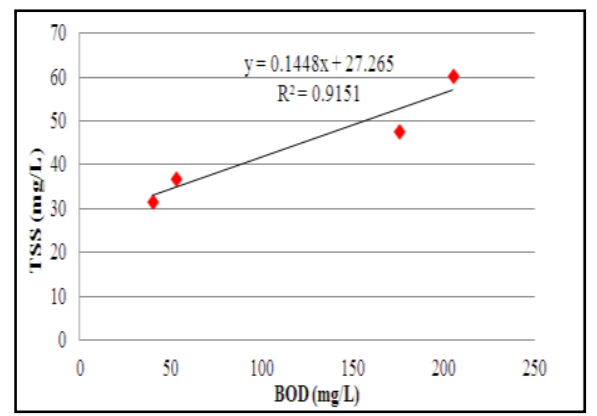

Figure 3. The regression analysis between TSS and BOD 
The COD concentration for pre-filtration raw greywater was slightly removed from the $1^{\text {st }}$ day until $28^{\text {th }}$ day. From the graph, the values of COD are decreased throughout the time. COD concentration against time (Figure 5) for $7^{\text {th }}$ day followed by 14th day and 28th day was $98 \mathrm{mg} / \mathrm{L}, 73 \mathrm{mg} / \mathrm{L}$ and $66 \mathrm{mg} / \mathrm{L}$, respectively indicate the removal process had done gradually. The result shows the overall weak performance of $51.36 \%$. The results shows that peat filters are not very effective on the removal of COD. This is agreed by [17] through their research showed that two types of peat, namely sapric (most decomposed) and fibric (least decomposed) peat performed equally well in removing the SS but performed unsatisfactorily in removing BOD and COD. On the other hand, [18] reported BOD and COD removal rates by sapric and fibirc peat were as $96 \%$ and $84 \%$ respectively.

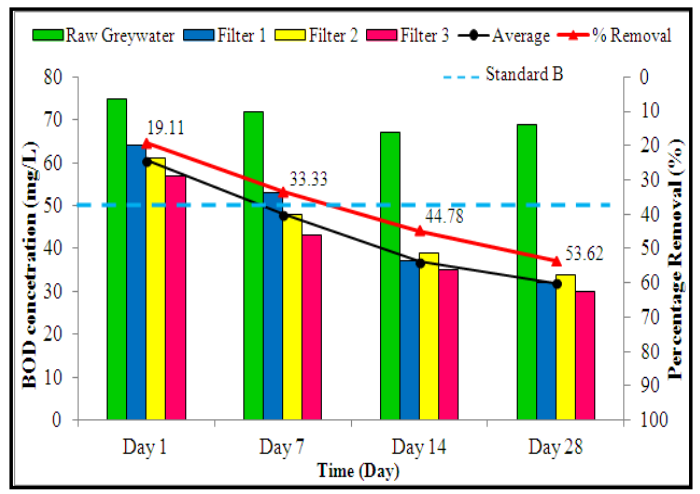

Figure 4. Concentration of BOD and its percentage removal during the treatment period

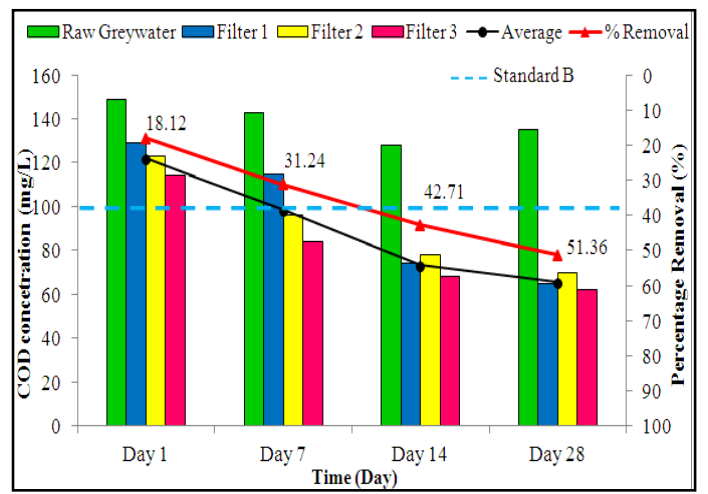

Figure 5. Concentration of $\mathrm{COD}$ and its percentage removal during the treatment period

For treated greywater using peat soil as filter media the value of Ammoniacal Nitrogen (AN) has concentration in the range of $1.5 \mathrm{mg} / \mathrm{L}$ and $8.3 \mathrm{mg} / \mathrm{L}$ (Figure 6). It shows that the value of AN was decreased to $87 \%$ after the filtration process. The decreased of AN value may be due cause of using charcoal as addition material on the filter system. Charcoal can be quite effective at removing some tastes, odors, and color of the water infiltration process [3]. The lowest concentration of AN recorded at $28^{\text {th }}$ day was $1.73 \mathrm{mg} / \mathrm{L}$ and comply with the permitted value for standard $\mathrm{B}$. The maximum value of standard B for AN before discharge for irrigation was $5.0 \mathrm{mg} / \mathrm{L}$. It shows that the treated greywater by using peat soil filtration are suitable to discharge for irrigation according to Environmental Quality (sewage) Regulation (DOE, 2009).

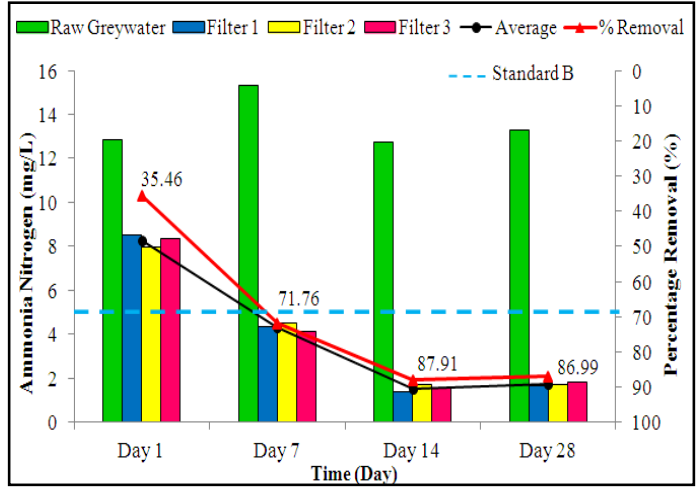

Figure 6. Concentration of $\mathrm{COD}$ and its percentage removal during the treatment period

\section{B. Effects of Peat Soil}

\section{One-Dimensional Consolidation}

Consolidation test was conducted to obtain the settlement of the samples when subjected to different loading. Figure 7 shows the relationship between void ratio and applied pressure for both the untreated and treated peat soil sample (i.e. after filtration process by using mixed greywater). It can be observed that both sample showed typical compressive characteristics of a soft material, with excessive settlement taking place with the first loading. It is also apparent that the loading-unloading curves of both samples showed very little difference in pattern, suggesting no change in the micro-fabric with negligible effect from the greywater passing through it. Nonetheless this could also be due to the relatively short retention time designated for the present study.

The initial void ratio was very different though, with the untreated sample containing $20 \%$ more pores or voids compared to the post-filtration sample, possibly caused by entrapment of fine materials during the filtration process. In addition, referring to Figure 2, the suspended solids in the filtered water showed a significant drop over the 28-day test period, suggesting an increase in the material retention rate in the peat media. This implies an increased efficiency of the peat filter media over time, due to the entrapped fines filling up the voids, as well as slime formed in the pores of the peat soil. However, as discussed earlier, this decrease in voids did not contribute to micro-fabric change for enhanced stiffness, resulting in very similar load-settlement responses for the samples, treated and untreated. In short, apart from the initial difference in the void ratio, both samples have undergone the same magnitude compression. 


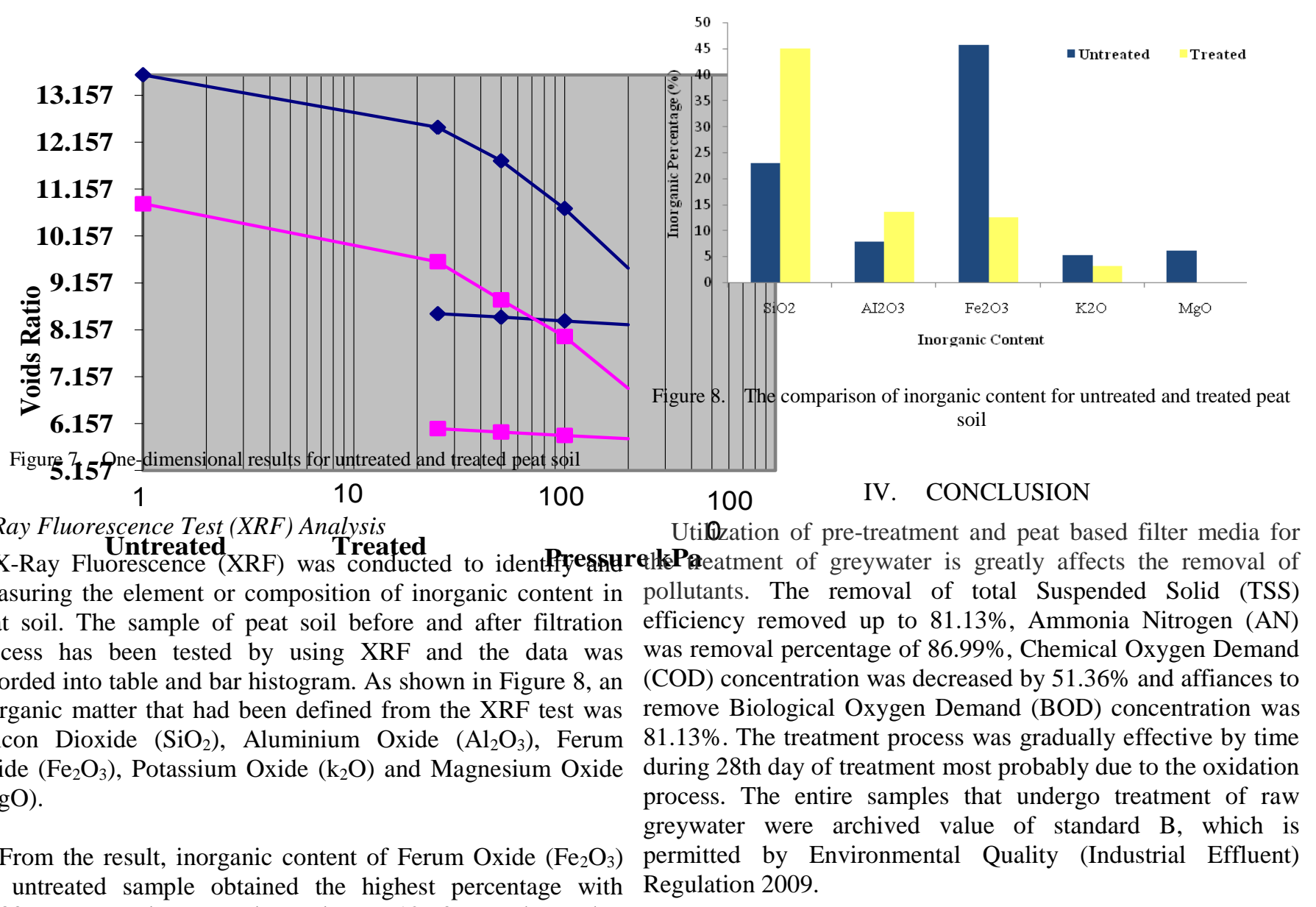
$45.80 \%$ compared to treated sample was $12.60 \%$. It shows that the Ferum Oxide $\left(\mathrm{Fe}_{2} \mathrm{O}_{3}\right)$ was reduced during the filtration process. This probably because of reaction between mixed greywater and peat soil can reduce the Ferum Oxide $\left(\mathrm{Fe}_{2} \mathrm{O}_{3}\right)$. Another percentage of inorganic content was found on untreated sample was Silicon Dioxide $\left(\mathrm{SiO}_{2}\right)$ with $22.30 \%$, Aluminium Oxide $\left(\mathrm{Al}_{2} \mathrm{O}_{3}\right)$ with $7.88 \%$, Potassium Oxide $\left(\mathrm{k}_{2} \mathrm{O}\right)$ with $5.15 \%$ and Magnesium Oxide $(\mathrm{MgO})$ was $0.30 \%$. From the Figure 9, some of the inorganic content was increase after the filtration process which was Silicon Dioxide $\left(\mathrm{SiO}_{2}\right)$ and Aluminium Oxide $\left(\mathrm{Al}_{2} \mathrm{O}_{3}\right)$.

The various household activities contribute the wide arrays of chemical content in greywater. According to [14] chemicals elements was present in many of our ordinary household chemicals, e.g. shampoos, perfumes, preservatives, dyes and cleaners. The efficiency of adsorption process will involves the groups present on the surface of the adsorbent materials and the pollutants chemisorption process. The basic chemisorptions involve the sharing of electrons between the pollutants and the surface of the adsorbent resulting into a chemical bond [9].

Analysis of the one-dimensional compressibility test results showed negligible effect of the greywater chemistry on the inherent stiffness, but this could be attributed to the rather short retention period preventing further chemical reactions or microstructuring. From the result of XRF test, peat soil contains an increased amount of the inorganic content of Silicon Dioxide $\left(\mathrm{SiO}_{2}\right)$ and Aluminium Oxide $\left(\mathrm{Al}_{2} \mathrm{O}_{3}\right)$. These findings had given initial hyphothesis that the chemical pollutants particles are absorbed by the peat and removed from the flow. The future research on the peat soil mechanism and their sorptive characteristics will answer those questions.

\section{ACKNOWLEDGMENT}

We thank Nor Sakinah Binti Mohamad, Hasyimah Ghani and Mohd Izumuddin Bin Jamian for the filter media experiment set up and analysis. The author wish to express thanks to the staff at the Environmental Engineering Laboratory, and also financial support from the Universiti Tun Hussein Onn Malaysia for this project. 


\section{REFERENCES}

[1] H.E. Muga, \& J.R. Mihelcic, "Sustainability of wastewater treatment technologies," Journal of Environmental Management. 88 (3), pp. 437447.2008.

[2] R.M.S.R. Mohamed, A.H.M. Kassim, M. Anda, S. Dallas, "A monitoring of environmental effects from household greywater reuse for garden irrigation," Environmental monitoring and assessment. 185 (10), pp. 8473-8488.2013.

[3] R.M.S.R. Mohamed, C.M. Chan, H. Ghani, M.A.M. Yasin, A.H.M. Kassim, "Application of Peat Filter Media in Treating Kitchen Wastewater," International Journal of Zero Waste Generation 1 (1), pp. 11-16. 2013.

[4] H. Palmquist \& J. Hanæus, "Hazardous substances in separately collected grey-and blackwater from ordinary Swedish households," Science of the Total Environment. 348(1-3), pp. 151-163.2005.

[5] F.E. Tang, A.H. Tan \& C.L.I. Ho, "Wastewater treatment systems for small cities in Sarawak". In Conference on Sustainable Building South East Asia. Malaysia.

[6] S. Deboucha, H. Roslan, and A. Alwi., "Engineering Properties of Stabilized Tropical Peat Soils," Journal of Geotechnical Engineering, 13, University of Malaya, Malaysia. 2008.

[7] E.C. Leong \& C.Y. Chin, "Geotechnical characteristics of peaty soils in southeast asia," Nanyang Technological University, School of Civil \& Structural Engineering, Singapore. 1997.

[8] P.A. Brown, S.A. Gill, \& J.J. Allen, "Metal removal from wastewater using peat," Water Research, 34 (16), pp. 3907-3916. 2001.

[9] M. Kõiv, R. Mõtlep, M. Liira, K. Kirsimäe and U. Mander, U. "The performance of peat-filled subsurface flow filters treating landfill leachate and municipal wastewater". Ecological Engineering, 35 (2), pp. 204-212. 2009.

[10] J.B. Xiong, and Q. Mahmood, "Adsorptive removal of phosphate from aqueous media by peat”. Desalination. 259 (1-3):59-64. 2010.

[11] CM Chan, RMSR Mohamed, "Post-Filtration Compressibility Characteristics of Peat Used as Greywater Filter Media," Middle-East Journal of Scientific Research, 17 (5), pp. 647-654. 2013.

[12] I. Ali, M. Asim \& T.A. Khan. "Low cost adsorbents for the removal of organic pollutants from wastewater," Journal of Environmental Management. 113 (2012), pp. 170-183. 2012.

[13] A. León-Torres, C. Fernández-González, M.F.A Alexandre Franco \& V. Gómez-Serrano. "On the use of a natural peat for the removal of $\mathrm{Cr}(\mathrm{VI})$ from aqueous solutions," Journal of Colloid and Interface Science. 386(1), pp. 325-332. 2012.

[14] APHA, AWWA, and WEF. "Standard Methods for the Examination of Water and Wastewater". 21st ed. American Public Health Association, Washington, DC. 2005.

[15] H.L. Hernández-Leal, G. Temmink, G., Zeeman, C.J.N. Buisman., "Removal of micropollutants from aerobically treated grey water via ozone and activated carbon." Water Research, 45(9), pp. 2887-2896. 2011.

[16] E. Eriksson, K. Auffarth, M. Henze \& A. Ledin. "Characteristics of grey wastewater." Urban Water. 4:85-104. 2002.

[17] J.I. Perez, E. Hontoria, M. Zamorano \& M.A. Gomez. "Wastewater treatment using a fibrist and saprist peat: A comparative study." Journal of Environmental Science and Health - Part A: Toxic/Hazardous Substances and Environmental Engineering, 40, pp. 1021-1032. 2005.

[18] M. Corley, M. Rodgers, J. Mulqueen \& E.Clifford. "The Performance of Fibrous Peat Biofilters in Treating Domestic Strength Wastewater." Journal of Environmental Science and Health, Part A: Toxic/Hazardous Substances and Environmental Engineering, 41(5): 170-183. 2006.

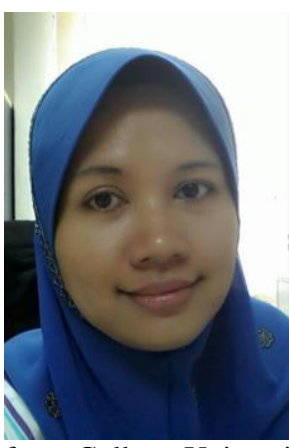

Dr. Radin Maya Saphira Radin Mohamed is a senior lecturer at Dept. of Water \& Environmental Engineering, Faculty of Civil \& Environmental Engineering, Universiti Tun Hussein Onn Malaysia. She did her PhD in Environmental Engineering (Greywater Recycling/Reuse for Irrigation), at Murdoch University, Perth, Australia. MEng (Research) in Civil Engineering (Environmental) with thesis titled 'River Modelling for Water quality in Bekok River' from College University Tun Hussein Onn Malaysia and BSc (Hons) in Industrial Chemistry, University Technology of Malaysia.

Dr. Radin Maya Saphira's research involves issues related to grey water management and soil qualities as well as their impact on the environment, and the search for practices to improve environmental quality related to contamination by greywater. In the last few years she has extended her research interest on the low-cost and sustainable technology to alleviate the greywater discharge pollution in the house villages. The use of natural sources and local soil are the most resources she interested for and she and her team of research have been conducted several research to fill the gap of research. 
GSTF International Journal of Engineering Technology (JET) Vol.2 No.4, April 2014 